\title{
ВЛИЯНИЕ АМОРФНОГО ДИОКСИДА КРЕМНИЯ НА РОСТОВЫЕ ПАРАМЕТРЫ ЯРОВОЙ ПШЕНИЦЫ
}

\author{
Yu.D. Smirnova, G.Yu. Rabinovich, V.O. Bulycheva
THE INFLUENCE OF AMORPHOUS SILICON DIOXIDE ON GROWTH PARAMETERS OF SPRING WHEAT

Смирнова Юлия Дмитриевна - канд. биол. наук, ст. науч. сотр. отдела биотехнологий ФИЦ «Почвенный институт им. В.В. Докучаева», Тверская обл., Калининский р-н, п. Эммаусс.

E-mail: ulayad@yandex.ru

Рабинович Галина Юрьевна - д-р биол. наук, проф., директор филиала ФИЦ «Почвенный институт им. В.В. Докучаева», Тверская обл., Калининский р-н, пос. Эммаусс.

E-mail:vniimz@list.ru

Бульчева Вероника Олеговна - инженерисследователь отдела биотехнологий ФИЦ «Почвенный институт им. В.В. Докучаева», Тверская обл., Калининский р-н, пос. Эммаусс. E-mail: vniimz@list.ru

Возросший интерес к препаратам кремния по всему миру является оправданным. Отмечается его положительное влияние на произрастание сельскохозяйственных культур в условиях абиотического стресса. Цель исследования - изучение влияния аморфного диоксида кремния Ковелос-Сорб на биометрические параметры растений яровой пшеницы при моделировании абиотических стрессов. КовелосСорб производства $О 00$ «Экокремний» представляет собой порошок с нанопористьми частицами размером от 5 до 100 мкм, с содержанием $\mathrm{SiO}_{2} 97$ \%. Ковелос-Сорб применяли для замачивания семян культуры, испытывали 0,05 \%; 0,25; 0,5 \% водные концентрации препарата. Семена проращивали в лабораторных условиях в пластиковых контейнерах с подготовленной дерново-подзолистой почвой по 21 шт. в каждом контейнере. Моделировались следующие абиотические стрессовые фракторы: недостаточная влажность (засуха), избыточная влажность, понижение температуры после посева. Наибольшее влияние препарата на биометрические показатели яровой пшеницы отмечено при использовании 0,5 \% концен-
Smirnova Yulia Dmitriyevna - Cand. Biol. Sci., Senior Staff Scientist, Department of Biotechnologies, FRC "V.V. Dokuchayev Soil Institute", Tver Region, Kalinin District, S. Emmauss.

E-mail: ulayad@yandex.ru

Rabinovich Galina Yuryevna - Dr. Biol. Sci., Prof., Director, Branch of FRC "V.V. Dokuchayev Soil Institute", Tver Region, Kalinin District, S. Emmauss.

E-mail: vniimz@list.ru

Bulycheva Veronika Olegovna - Research Engineer, Department of Biotechnologies, FRC "V.V. Dokuchayev Soil Institute", Tver Region, Kalinin District, S. Emmauss.

E-mail: vniimz@list.ru

трации Ковелос-Сорб при проращивании яровой пшеницы в условиях засухи и понижения температуры после посева. При моделировании засухи увеличение длины проростка составило $7,8 \%$, сырой массы - 14,4, сухой массы проростка - 15,0, в условиях понижения температуры - 25, 7 и 15 \% соответственно по сравнению с семенами, не обработанными кремнием. В условиях без стресса и при повышенной влажности применение аморфного кремния не способствовало значимым приростам биометрических показателей. Более крепкие проростки яровой пшеницы, сорормированные под влиянием аморфного кремния, повышали устойчивость растений к моделируемым абиотическим стрессам. Рекомендуется применение КовелосСорб в качестве антистрессового препарата.

Ключевые слова: аморфный диоксид кремния Ковелос-Сорб, яровая пшеница, абиотические стрессы.

Increased interest in silicon preparations around the worldwide is justified. Its positive effect on the growth of crops under abiotic stress is noted. The aim of the research was to study the effect of amor- 
phous silicon dioxide Kovelos-Sorb on biometric parameters of spring wheat plants when modeling abiotic stresses. Kovelos-Sorb produced by LLC 'Ecocremniy', a powder with nanoporous particles ranging in size from 5 to 100 microns, with a $\mathrm{SiO}_{2}$ content of $97 \%$. Kovelos-Sorb was used to soak the seeds of the culture; $0.05 \%, 0.25,0.5 \%$ aqueous concentrations of the preparation was tested. The seeds were grown in laboratory conditions in plastic containers with prepared sod-podzolic soil of 21 pcs. in each container. The following abiotic stress factors were modeled: insufficient humidity (drought), excessive humidity, and the decrease in the temperature after sowing. The greatest effect of the drug on biometric parameters of spring wheat was noted when using a $0.5 \%$ concentration of Kovelos-Sorb during spring wheat germination under conditions of drought and lowering the temperature after sowing. In modeling droughts the increase the length of seedling was $7.8 \%$, crude mass by 14.4 , dry weight of seedling - 15.0, in terms temperature reduction 25,7 and $15 \%$, respectively compared to the seeds not treated with silicon. In the conditions without stress and at high humidity, the use of amorphous silicon did not contribute to significant increases in biometric indicators. Stronger spring wheat seedlings formed under the influence of amorphous silicon increased plant resistance to simulated abiotic stresses. The use of Kovelos-Sorb as an anti-stress preparation is recommended.

Keywords: amorphous silicon dioxide KovelosSorb, spring wheat, abiotic stresses.

Введение. В последнее время возрос интерес к применению соединений кремния при выращивании различных сельскохозяйственных культур. Практика сельского хозяйства многих стран мира свидетельствует о значительной эфффективности кремниевых удобрений и росте их потребления [1-3]. Функции кремния в растениях выражаются в формировании механической, фризиологической и биохимической защиты от биотических и абиотических стрессов [4]. Больше всего представляют интерес результаты исследований по повышению сопротивляемости растений к неблагоприятным фракторам внешней среды: засухе, высоким и низким температурам, засолению, УФ-излучению, поражению вредителями, грибковыми и бактериальными болезнями и пр. $[5,6]$. Воздействие кремния связано с улучшением условий питания растений, влиянием на многие фризиолого- биохимические процессы, участием в оптимизации транспорта и перераспределении веществ внутри растения [7].

На практике препараты кремния применяют в различных модификациях - это некоторые горные породы (диатомиты и цеолиты), кремниевая кислота и ее соль метасиликат натрия, ряд коммерческих препаратов, а также аморфный диоксид кремния [8-11]. Выпускаемый ООО «Экокремний» высокочистый синтетический аморфный диоксид кремния под торговой маркой Ковелос-Сорб представляет собой очень легкий микронизированный (размер частиц от 5 до 100 мкм) порошок белого цвета без вкуса и запаха с нанопористой структурой частиц, с содержанием $\mathrm{SiO}_{2} 97$ \% [12]. Его частицы имеют сложную пространственную структуру, создающую огромную удельную площадь поверхности 300-350 M2/r.

Цель исследования. Изучить влияние аморфного диоксида кремния Ковелос-Сорб на биометрические параметры растений яровой пшеницы при моделировании абиотических стрессов.

Материал и методы исследования. Оценку влияния препарата проводили в лабораторном эксперименте путем моделирования стрессовых условий для растений яровой пшеницы сорта Иргина. Дерново-подзолистую почву, имеющую агрохимическую характеристику - $\mathrm{pH}-4,31$; $\mathrm{P}_{2} \mathrm{O}_{5}-192,1 ; \mathrm{K}_{2} \mathrm{O}-156,2 ;$ Nлг. - 35,1 мг/кг, гумус - 2,83 \%, высушивали до воздушно-сухого состояния, просеивали, раскладывали в пластиковые контейнеры по 150 г и увлажняли до $70 \%$ от НВ. В каждый контейнер сеяли по 21 семени яровой пшеницы. Ковелос использовался для замачивания семян перед посевом в трех концентрациях - 0,05\%; 0,25; 0,5\%. Поскольку аморфный оксид кремния практически нерастворим в воде, семена замачивали в растворе при непрерывном перемешивании в течение 1 часа. В контрольном варианте семена замачивали в воде.

Моделировались следующие стрессовые факторы:

- засуха путем прекращения полива растений (на 5-е сутки после посева); стрессовое воздействие продолжали до начала увядания растений - достигнутая влажность почвы $10 \%$ от НB, затем ее увлажнили до $70 \%$ от HB;

- избыточная влажность до наступления 140 \% от НВ путем дополнительного полива в 
фазу всходов (на 5-е сутки после посева); стрессовое воздействие - двое суток;

- постепенное понижение температуры с 23 до $7^{\circ} \mathrm{C}$ после посева, что имитировало естественное природное понижение температуры; стрессовое воздействие - двое суток.

Также были заложены варианты с произрастанием семян без моделирования стресса. Эксперимент проводили в течение 2 недель, для поддержания заданной влажности осуществляли регулярный полив, повторность опыта трехкратная.

Для определения степени влияния предпосевной обработки семян на растения яровой пшеницы проводили определение длины проростков, сырой и сухой массы проростков растений, сухой массы корней.

Статистическую обработку данных проводили в пакете Microsoft Excel, представлены среднеарифметические значения с доверительным интервалом.

Результаты и их обсуждение. Предпосевная обработка семян яровой пшеницы препаратом в различных концентрациях оказывала влияние на биометрические показатели ее проростков. Степень воздействия аморфного оксида кремния различалась в зависимости от моделируемого стресса (табл.).

\section{Биометрические показатели проростков яровой пшеницы}

\begin{tabular}{|c|c|c|c|c|}
\hline Концентрация & $\begin{array}{c}\text { Средняя длина } \\
1 \text { проростка, см }\end{array}$ & $\begin{array}{c}\text { Средняя сырая мас- } \\
\text { са 1 проростка, } \\
\text { х10-3 }\end{array}$ & $\begin{array}{c}\text { Средняя сухая } \\
\text { масса 1 проро- } \\
\text { стка, х10-3 }\end{array}$ & $\begin{array}{c}\text { Средняя сухая мас- } \\
\text { са корешков с 1 рас- } \\
\text { тения, х10-3 }\end{array}$ \\
\hline \multicolumn{5}{|c|}{ Без моделирования стресса } \\
\hline Вода & $19,9 \pm 0,9$ & $92,8 \pm 3,8$ & $12,8 \pm 0,5$ & $7,25 \pm 0,28$ \\
\hline $0,05 \%$ & $20,3 \pm 0,9$ & $93,1 \pm 4,2$ & $12,4 \pm 0,5$ & $7,24 \pm 0,34$ \\
\hline $0,25 \%$ & $20,2 \pm 1,0$ & $88,1 \pm 3,5$ & $12,6 \pm 0,6$ & $7,23 \pm 0,30$ \\
\hline $0,5 \%$ & $20,9 \pm 0,8$ & $94,4 \pm 3,7$ & $12,9 \pm 0,4$ & $7,36 \pm 0,31$ \\
\hline \multicolumn{5}{|c|}{ Стресс- недостаточная влажность (засуха) } \\
\hline Вода & $18,0 \pm 0,8$ & $87,1 \pm 3,0$ & $10,7 \pm 0,5$ & $6,54 \pm 0,25$ \\
\hline $0,05 \%$ & $18,7 \pm 0,9$ & $94,9 \pm 3,2$ & $11,6 \pm 0,3$ & $6,66 \pm 0,23$ \\
\hline $0,25 \%$ & $18,2 \pm 0,9$ & $96,5 \pm 4,0^{*}$ & $11,3 \pm 0,4$ & $6,52 \pm 0,30$ \\
\hline $0,5 \%$ & $19,4 \pm 1,0$ & $99,6 \pm 3,8^{*}$ & $12,1 \pm 0,5^{*}$ & $6,58 \pm 0,20$ \\
\hline \multicolumn{5}{|c|}{ Стресс- повышенная влажность } \\
\hline Вода & $22,4 \pm 1,0$ & $104,6 \pm 4,2$ & $10,8 \pm 0,4$ & $3,34 \pm 0,10$ \\
\hline $0,05 \%$ & $21,2 \pm 1,1$ & $100,5 \pm 3,5$ & $11,0 \pm 0,5$ & $3,67 \pm 0,12^{*}$ \\
\hline $0,25 \%$ & $22,1 \pm 0,9$ & $102,5 \pm 4,6$ & $11,1 \pm 0,5$ & $3,76 \pm 0,18^{*}$ \\
\hline $0,5 \%$ & $22,0 \pm 0,9$ & $101,1 \pm 4,1$ & $11,2 \pm 0,4$ & $4,43 \pm 0,16^{*}$ \\
\hline \multicolumn{5}{|c|}{ Стресс- понижение температуры после посева } \\
\hline Вода & $17,6 \pm 0,7$ & $78,4 \pm 3,7$ & $10,1 \pm 0,6$ & $6,25 \pm 0,18$ \\
\hline $0,05 \%$ & $18,7 \pm 0,9$ & $92,7 \pm 4,0^{*}$ & $11,0 \pm 0,4$ & $6,44 \pm 0,25$ \\
\hline $0,25 \%$ & $18,7 \pm 0,8$ & $92,7 \pm 3,9^{*}$ & $11,5 \pm 0,3^{*}$ & $7,05 \pm 0,28^{*}$ \\
\hline $0,5 \%$ & $18,8 \pm 0,4$ & $98,3 \pm 4,2^{*}$ & $11,6 \pm 0,5^{*}$ & $6,42 \pm 0,32$ \\
\hline
\end{tabular}

* - обозначены значения параметров, достоверно отличающиеся от соответствующих контролей при $p \leq 0,05$.

При проращивании пшеницы в условиях без моделирования стресса влияние препарата фиксировали только в концентрации 0,5\%: наблюдалось увеличение длины проростка на $5 \%$ и незначительный прирост сырой массы - на 1,7 \% (табл.). Схожее положительное воздейст- вие данного препарата получено в исследованиях Брянского государственного университета, проведенного с 12 видами культурных растений, - выявили увеличение всхожести семян, длин проростков и корней, а также повышение содержания в побегах аскорбиновой кислоты [10]. 
В условиях засухи отмечалось выраженное действие предпосевной обработки семян на проростках пшеницы - процент увеличения прироста всех биометрических параметров наблюдали с ростом концентрации рабочего раствора препарата. Соответственно увеличение длины проростка от 0,5\%-го раствора составило 7,8 \%, сырой массы проростка - 14,4, сухой массы - 13,0 \% (см. табл.).

В условиях повышенной влажности особо значимых изменений по определяемым биометрическим показателям проростков пшеницы не выявлено, можно отметить тенденцию увеличения сухой массы проростка. Но стоит отметить повышение сухой массы корешка при применении концентраций 0,25 и 0,5\% в среднем на $11 \%$ (см. табл.).

При моделировании понижения температуры после посева отмечали явное положительное действие препарата на проростки пшеницы, при этом рост биометрических показателей проходил с увеличением применяемой концентрации (табл.). Наибольший прирост сырой массы проростков составил $25 \%$, при этом длина увеличилась на $7 \%$, сухая масса проростка - на $15 \%$, корешка - на $3 \%$.

Выраженный стимулирующий эфффект препаратов кремния в условиях холодового стресса также отмечен авторами [13]. При обработке семян овощных культур перед посевом золем диоксида кремния длина проростков гороха возросла в 2,7 раза, корней - в 1,7 раза; побегов томата - в 1,8 раза, корней - в 2 раза; побегов моркови - в 1,6 раза, корней - в 1,5 раза по сравнению с контрольным вариантом.

Увеличение биометрических параметров проросших семян яровой пшеницы в результате применении аморфного оксида кремния Ковелос-Сорб для предпосевной обработки свидетельствовало об ускоренении ростовых процессов у культуры по сравнению с контролем. Значительные приросты сырой массы проростков свидетельствовали о накоплении в клетках дополнительного количества влаги за счет образования гидрофильных силикатно-галактозных комплексов, что повышает их устойчивость к абиотическим стрессам [5]. Увеличение сухой массы проростков указывает на наращивание тканей растения, что придает проросткам дополнительную прочность. Более развитая кор- невая система способствует не только лучшему поглощению воды и питательных веществ, но и образованию органических веществ (аминокислот, амидов, алкалоидов).

Заключение. Эксперимент показал положительное влияние аморфного оксида кремния на ростовые показатели яровой пшеницы на ранней стадии онтогенеза. Установлено, что лучшие биометрические параметры проростков яровой пшеницы получены при предпосевной обработке семян 0,5\%-м водным раствором препарата Ковелос-Сорб. Наибольший прирост величин наблюдали при моделировании засухи и понижении температуры после посева. При имитировании повышенной влажности почвы и в условиях без стресса значимых положительных изменений, как и негативных (ингибирующих), по изучаемым параметрам не отмечено. Более развитые побеги и корневая система проростков яровой пшеницы позволяют в дальнейшем спрогнозировать и более мощную вегетативную систему на следующих стадиях онтогенеза, что в последующем отразится на увеличении урожайности культуры, даже в условиях негативного воздействия абиотических стрессов.

\section{Литература}

1. Merwad A.R.M.A. Response of yield and nutrients uptake of pea plants to silicate under sandy soil conditions // Communications in Soil Science and Plant Analysis. 2018. Vol. 49. №. 13. P. 1553-1562. DOI: 10.1080/00103624. 2018.1474895.

2. Maghsoudi K., Emam Y., Pessarakli M. Effect of silicon on photosynthetic gas exchange, photosynthetic pigments, cell membrane stability and relative water content of different wheat cultivars under drought stress conditions /I Journal of Plant Nutrition. 2016. Vol. 39. № 7. P. 1001-1015. DOI: 10.1080/01904167.2015. 1109108.

3. Уромова И.П., Лобина В.С. Применение регулятора роста СИЛК на картофеле // Успехи современного естествознания. 2016. № 6. C.110-113.

4. Самсонова Н.E., Капустина М.В., Зайцева З.Ф. Влияние соединений кремния и минеральных удобрений на урожайность яровых зерновых культур и содержание в них 
антиоксидантных ферментов // Агрохимия. 2013. № 10. C. 66-74.

5. Лось С.Л., Борздыко Е.В., Анищенко Л.Н. [и др.]. Устойчивость культурных растений к биотическим стрессам в условиях модельного использования препарата Ковелос // Proceedings of the 13th International Academic Conference «Applied and fundamental studies». USA, Missouri, St. Louis, 2017. C. 11-18.

6. Козлов Ю.В., Самсонова Н.Е. Использование соединений кремния при выращивании зерновых культур // Плодородие. 2009. № 6. C. 20-21.

7. Haynes R.J. Significance and role of Si in crop production // Advances in Agronomy. 2017. Vol. 146. P. 83-166. DOI: 10.1016/bs.agron. 2017.06.001.

8. Матьченков В.В., Кособрихов А.А., Шабнова Н.И. [и др.]. Кремниевые удобрения как фактор повышения засухоустойчивости // Агрохимия. 2007. № 5. С. 63-67.

9. Смывалов В.С., Захарова Д.А., Яшин А.Е. Влияние кремнийсодержащих материалов и минерального удобрения на биологическую активность чернозема выщелочного // Вестник Ульяновской государственной сельскохозяйственной академии. 2017. № 3 (39). C. 19-25. DOI: 10.18286/1816-45012017-3-19-25.

10. Анищенко Л.Н., Борздыко Е.В., Москаленко И.В. [и др.]. Влияние аморфного диоксида кремния на ростовые и биохимические показатели культурных растений на ранних стадиях онтогенеза // Успехи современного естествознания. 2017. № 3. С. 40-45.

11. Савченко О.М., Козловская Л.Н., Маланкина Е.Л. [и др.]. Взаимодействие регулятора роста «Циркон» и микроудобрения «Силиплант» при вегетативном размножении Allium Ursinuv L. и Allium Victorialis subsp. Platyphyllum (Hultun) Makino // Вестник КрасГАУ. 2019. № 1 (142). С. 45-50.

12. Об аморфном диоксиде кремния. Заголовок с сайта «Научно-производственное предприятие 000 «Экокремний». URL: http://aerosil.su/ob-amorfnom-dioksidekremniya (дата обращения: 18.01.2019).

13. Разлуго И.А., Немцова Е.В. Влияние аморфного диоксида кремния и его золя на параметры роста некоторых овощных куль- тур // Плодоводство и ягодоводство России. 2018. T. 55. C. 142-146. DOI: $10.31676 / 2073-$ 4948-2018-55-142-146.

\section{Literatura}

1. Merwad A.R.M.A. Response of yield and nutrients uptake of pea plants to silicate under sandy soil conditions // Communications in Soil Science and Plant Analysis. 2018. Vol. 49. №. 13. P. 1553-1562. DOI: 10.1080/00103624. 2018.1474895.

2. Maghsoudi K., Emam Y., Pessarakli M. Effect of silicon on photosynthetic gas exchange, photosynthetic pigments, cell membrane stability and relative water content of different wheat cultivars under drought stress conditions /I Journal of Plant Nutrition. 2016. Vol. 39. № 7. P. 1001-1015. DOI: 10.1080/01904167.2015. 1109108.

3. Uromova I.P., Lobina V.S. Primenenie reguljatora rosta SILK na kartofele // Uspehi sovremennogo estestvoznanija. 2016. № 6 . S.110-113.

4. Samsonova N.E., Kapustina M.V., Zajceva Z.F. Vlijanie soedinenij kremnija i mineral'nyh udobrenij na urozhajnost' jarovyh zernovyh kul'tur i soderzhanie $v$ nih antioksidantnyh fermentov // Agrohimija. 2013. № 10. S. 66-74.

5. Los' S.L., Borzdyko E.V., Anishhenko L.N. [l dr.]. Ustojchivost' kul'turnyh rastenij $\mathrm{k}$ bioticheskim stressam v uslovijah model'nogo ispol'zovanija preparata Kovelos // Proceedings of the 13th International Academic Conference "Applied and fundamental studies». USA, Missouri, St. Louis, 2017. S. 11-18.

6. Kozlov Ju.V., Samsonova N.E. Ispol'zovanie soedinenij kremnija pri vyrashhivanii zernovyh kul'tur // Plodorodie. 2009. № 6. S. 20-21.

7. Haynes R.J. Significance and role of $\mathrm{Si}$ in crop production // Advances in Agronomy. 2017. Vol. 146. P. 83-166. DOI: 10.1016/bs.agron. 2017.06.001.

8. Matychenkov V.V., Kosobrshhov A.A., Shabnova N.I. [i dr.]. Kremnievye udobrenija kak faktor povyshenija zasuhoustojchivosti // Agrohimija. 2007. № 5. S. 63-67.

9. Smyvalov V.S., Zaharova D.A., Jashin A.E. Vlijanie kremnijsoderzhashhih materialov i mineral'nogo udobrenija na biologicheskuju 
aktivnost' chernozema vyshhelochnogo // Vestnik Ul'janovskoj gosudarstvennoj sel'skohozjajstvennoj akademii. 2017. № 3 (39). S. 1925. DOI: 10.18286/1816-4501-2017-3-19-25.

10. Anishhenko L.N., Borzdyko E.V., Moskalenko I.V. [i dr.]. Vlijanie amorfnogo dioksida kremnija na rostovye i biohimicheskie pokazateli kul'turnyh rastenij na rannih stadijah ontogeneza // Uspehi sovremennogo estestvoznanija. 2017. № 3. S. 40-45.

11. Savchenko O.M., Kozlovskaja L.N., Malankina E.L. [i dr.]. Vzaimodejstvie reguljatora rosta «Cirkon» i mikroudobrenija «Siliplant» pri vegetativnom razmnozhenii Allium Ursinuv L. i
Allium Victorialis subsp. Platyphyllum (Hultun) Makino // Vestnik KrasGAU. 2019. № 1 (142). S. $45-50$.

12. Ob amorfnom diokside kremnija. Zagolovok $s$ sajta «Nauchno-proizvodstvennoe predprijatie 000 «Jekokremnij». URL: http://aerosil.su/obamorfnom-diokside-kremniya (data obrashhenija: 18.01.2019).

13. Razlugo I.A., Nemcova E.V. Vlijanie amorfnogo dioksida kremnija i ego zolja na parametry rosta nekotoryh ovoshhnyh kul'tur // Plodovodstvo i jagodovodstvo Rossii. 2018. T. 55. S. 142-146. DOI: 10.31676/2073-49482018-55-142-146. 